\title{
ASSESSMENT OF OPEN DEFECATION FREE (ODF) CAMPAIGN OF BIRGUNJ SUB METROPOLITAN CITY BY FECAL INDICATOR MICRO BES ANALYSIS
}

\author{
Umesh Prasad Sh rivastava \\ Department of Botany, TU, Thakur Ram Multiple Campus, Birgunj, N epal \\ E-mail: upshrivastava@gmail.com
}

\begin{abstract}
Eliminating open defecation is increasingly seen as a health outcome, improved educational and positive health outcomes for Several countries including Nepal have set aggressive targets for elimination of Open Defecation in urban and rural areas, which often include not only safe disposal of feces, but handwashing facilities, cleanliness and solid waste ma ement. This paper is prepared based on the evaluation of representative water reservoirs of six sites of Birgunj municipality with an objective to examine fecal microorganisms. Presence of Cryptosporidium, Giardia, Citrobacter, Ent robacter, Klebsiella, Escherichia etc were observed. Although these wards have been declared ODF by municipality. This paper report the partial success toward ODF in Birgunj metropolitan and recommend post monitoring for ODF for sustainable ODF is required.
\end{abstract}

\section{Ke y words}

Open Defecation; ODF; Fecal indicator microbes; Birgun

\section{Introduction}

Cryptosporidium is a genus of apicomplexan protozoans that can cause a respiratory and gastrointestinal sickness (cryptosporidiosis) that primarily involves watery diarrhea (intestinal cryptosporidiosis) with or without a persistent cough (respiratory cryptosporidiosis) in both immunocompetent and immune-deficient humans (Sponseller et al., 2014) (Fig. 1A). Cryptosporidium, the parasites havealifecyclethatcan becompleted in humans and many types of animals. The disease cryptosporidiosis is spread from person to person after the parasites are shed into the environment; they may be found in soil, food, water, or on surfaces that have been contaminated with feces from infected humans or animals.

Similarly, Giardia is a genus of anaerobic flagellated protozoan parasites of the phylum Sarcomastigophora that colonise and reproduce in the small intestines of several

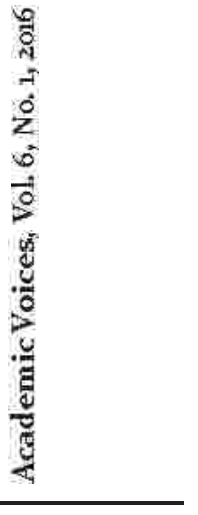




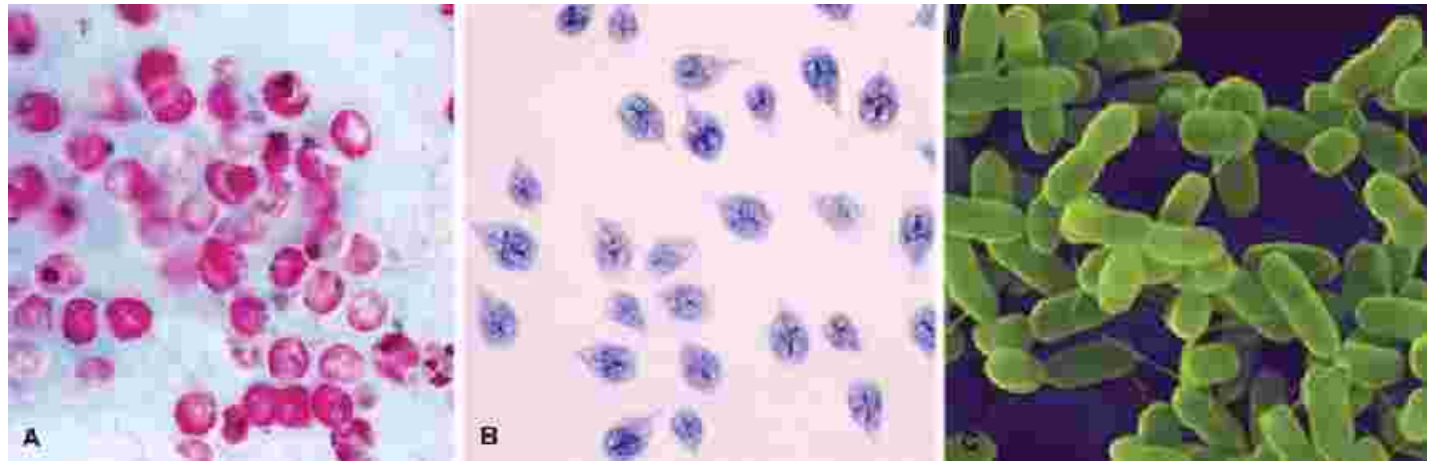

Fig. 1: Microphotograph of fecal indicator Microbes, A. Cryptosporidium sp.; B. Giardia sp.; C. Coliform bacteria (Escherichia coli).

vertebrates, causing giardiasis (Fig. 1B). Their life cycle alternates between an actively swimming trophozoite and an infective, resistant cyst. Giardia were first described by the Dutch microscopist Antonie van Leeuwenhoek in 1681 (Stanley et al., 1984). The genus is named after French zoologist Alfred Mathieu Giard (Adam, 2001).

Coliform bacteria are a commonly used indicator of sanitary quality of foods and water (Fig. 1C). They are defined as rodshaped Gram-negative non-spore forming and motile or non-motile bacteria which can ferment lactose with the production of acid and gas when incubated at $35-37^{\circ} \mathrm{C}$ (APHA, 1995). Coliforms can be found in the aquatic environment, in soil and on vegetation; they are universally present in large numbers in the feces of warm-blooded animals. While coliforms themselves are not normally causes of serious illness, they are easy to culture, and their presence is used to indicate that other pathogenic organisms of fecal origin may be present. Such pathogens include disease-causing bacteria, viruses, or protozoa and many multicellular parasites. Coliform procedures are performed in aerobic or anaerobic conditions. Typical genera include: Citrobacter, Enterobacter, Hafnia, Klebsiella, Escherichia etc.

Escherichia coli (E. coli), arod-shaped member of the coliform group, can be distinguished from most other coliforms by its ability to ferment lactose at $44^{\circ} \mathrm{C}$ in the fecal coliform test, and by its growth and color reaction on certain types of culturemedia. W hen cultured on an eosin methylene blue (EMB) plate, a positive result for $E$. coli is metallic green colonies on a dark purple media. Escherichia coli have an incubation period of $\mathrm{D}-72$ hours with the optimal growth temperature being $30-37^{\circ} \mathrm{C}$. Unlike the general coliform group, E. coli are almost exclusively of fecal origin and their presence is thus an effective confirmation of fecal contamination. Most strains of $E$. coli are harmless, but some can cause serious illness in humans. Infection symptoms and signs include bloody diarrhea, stomach cramps, vomiting and occasionally, fever. The bacteria can also cause pneumonia, other respiratory illnesses and urinary tract infections (Todar, 2007; Scallan et al., 2011).

An easy way to differentiate between different types of coliform bacteria is by using an eosin methylene blue agar plate. This plate is partially inhibitory to Gram (+) bacteria, and will produce a color change in the Gram (-) bacterial colonies based on lactose fermentation abilities. Strong lactose fermenters will appear as dark blue/purple/ black, and E. coli (which also ferments lactose) colonies will be dark colored, but will also appear to have a metallic green sheen. Other coliform bacteria will appear as thick, slimy colonies, with non-fermenters being colorless, and weak fermenters being pink. (Fig 1) 
Fecal microbiota transplant (FMT), also known as a stool transplant, is the process of transplantation of fecal bacteria from ahealthy individual into a recipient. FMT involves restoration of the colonic microflora by introducing healthy bacterial flora through infusion of stool, e.g. by enema, orogastric tube or by mouth in the form of a capsule containing freeze-dried material, obtained from a healthy donor. A limited number of studies have shown it to be an effective treatment for patients suffering from Clostridium difficile infection (CDI), which can range from diarrhea to pseudomembranous colitis (https://en.wikipedia.org/wiki/Fecal_ microbiota_transplant).

Due to an epidemic of CDI in North America and Europe, FMT has gained increasing prominence, with some experts calling for it to become first-line therapy for CDI. In 2013, a randomized, controlled trial of FMT from healthy donors showed it to be highly effective in treating recurrent $C$. difficile in adults and more effective than vancomycin alone. FMT has been used experimentally to treat other gastrointestinal diseases, including colitis, constipation, irritable bowel syndrome, and neurological conditions (such as multiple sclerosis and Parkinsor's. In the United States, the Food and Drug Administration (FDA) has regulated human feces as an experimental drug since 2013 (https://en.wikipedia.org/wiki/Fecal_ microbiota_transplant).

Fecal pathogen contamination of watersheds worldwide is increasingly recognized, and natural water bodies may have an important role in mitigating fecal pathogen pollution flowing downstream. Given that waterborne protozoa, such as Cryptosporidium and Giardia, are transported within surface waters, this study evaluated associations between fecal protozoa and various wetland-specific and environmental risk factors.

The main objective of the present study focus the evaluation of the ODF program of Birgunj municipality by examining the important water reservoirs situated to various wards. It is well known that drainage of rainwater along with fecal material inters in the various water reservoirs and pond in the locality.

\section{Materials \& methods}

\section{Study sites and water samples:}

The ward wise map of Birgunj submetropolitan city showing study sites is shown in Fig. 2. In course of selecting major water bodied, 6 ponds were identified as storage of drained fecal materials. Water samples of these ponds analyzed at the interval of three months between June 2015 and June 2016. 1 liter water sample from 4-5 different places/corners of pond was collected in sterile containers. All samples from one ponds were mixed properly and after mixing, 1 liter sample was used for analysis. Similar process was adopted for all six locations. If possible experimental works proceeded in the laboratory of department of Botany, T.R.M. Campus on same day otherwise the samples were stored at $40^{\circ} \mathrm{C}$. Municipal ward number of studied sites has been listed in Table 1

Table r: Municipal ward wise list of location of study

\begin{tabular}{c|c} 
Location of study & $\begin{array}{c}\text { Municipal ward } \\
\text { number }\end{array}$ \\
Site 1 & 2 \\
\hline Site 2 & 19 \\
\hline Site 3 & 19 \\
\hline Site 4 & 13 \\
\hline Site 5 & 10 \\
\hline Site 6 & 17 \\
\hline
\end{tabular}

\section{Culture Media}

Thefollowing culture media were used in this study:-For presumptive coliforms test Lactose broth LB (Oxoid) was used, Brilliant Green Lactose Bile Broth BGLB (Oxoid) and Eosine Nethylene Blue agar EMB (Difco) were used 
for confirmatory feacal coliforms, Ringers solution (Oxoid). Plate count agar PCA (Oxoid) and Mac Conkey's agar (Difco) were used for standard plate count and coliform counts, selenite broth (Difco), Peptone (Oxoid), Sodium Chloride $\mathrm{NaCl}$ (Merck), Xylose lysine dextrose, medium XLD (Oxoid) and Thiosuiphate citrate bile salts sucrose agar TCBS (O xoid) were used for special tests, and other biochemical tests were used for identification of the isolates.

\section{Presumptive tests for coliforms (MPN)}

Following strict aseptic procedures, the sample was shaken vigorously and inoculated in 2 tubes of lactose broth, one with $10 \mathrm{ml}$ and the other with $0.1 \mathrm{ml}$ of sample, and 5 tubes of double strength $(2 \mathrm{~N})$ lactose broth, each with $10 \mathrm{ml}$ of sample and $10 \mathrm{ml}$ of the medium with inverted Durham tubes. Inoculated tubes were incubated at $35^{\circ} \mathrm{C}$ for 48 hours. Following the incubation period results were recorded. If no gas was formed within 48 hours this constituted a negative presumptive test. The presence of $10 \%$ or more gas displacement in any of the Durham tubes was considered a positive presumptive test. The most probable number (MPN) for the water sample tested was recorded by number of positive tubes, containing gas in the series of 7 tubes and consulting MPN table (Rand et al., 1976).

\section{Standard plate count for water (SPC)}

The standard plate count was done by pour plate technique. Prepared 10 fold dilutions, each tube containing $9 \mathrm{ml}$ of ringers solution. Dilutions were made upto $10-6$.

Accurately measuring $1 \mathrm{ml}$ from each dilution was inoculated in duplicate empty and sterilized Petri-dishes. About 12 to $15 \mathrm{ml}$ of plate count agar al ready kept at $45^{\circ} \mathrm{C}$ in a water bath was added to each plate. Plates were gently rotated after pouring the media and allowed to set and were incubated in an inverted position at $35^{\circ} \mathrm{C}$ for 24 to 48 hours.

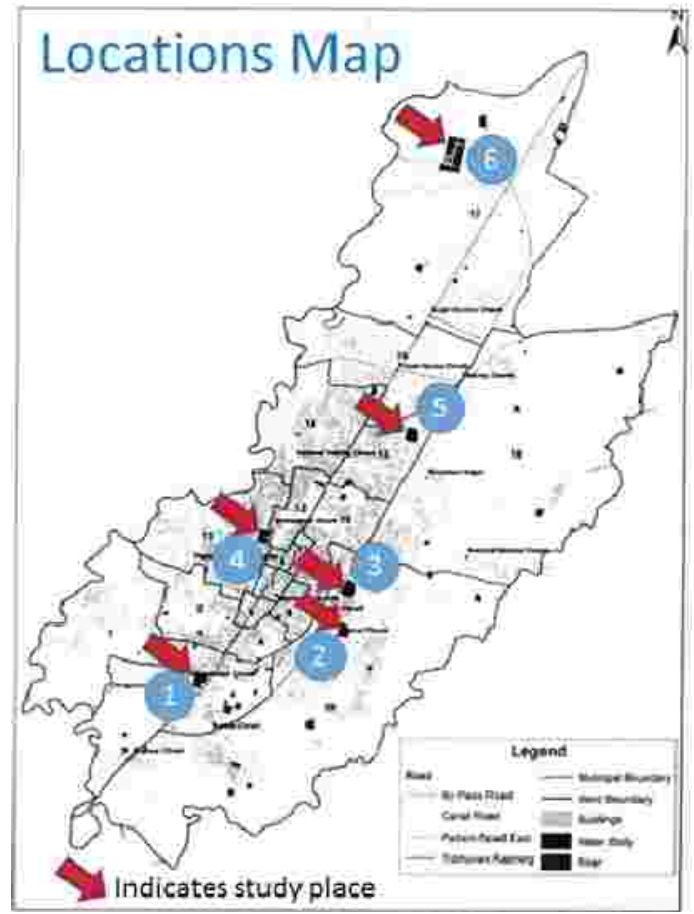

Fig. 2: Map of Birgunj sub-metropolitan city showing locations of sample collections for analysis of fecal indicator microbes.

The surface and subsurface bacterial colonies thus received were counted. Plates showing 30-300 colonies were counted to determine the SPC per $\mathrm{ml}$ of sampletested.

\section{Identification of the isolates}

For the identification of the isolates from the water samples, biochemical tests were performed as per the standard protocols (Benson, 1998; Sobsey and Pfaender, 2002).

\section{Results \& discussion}

Data presented on the Fig 3 clearly shows that MPN of organisms per $100 \mathrm{ml}$ water sample showed a decrease in June 2016 in respect to June 2015 in all the six sites. Therefore, the study indicates the slow success of the ODF program. However, maximum MPN of organisms per $100 \mathrm{ml}$ is highest in the month of December 2015. The study was started in the beginning of rainy season ie. June 2015 and 
Table 1: Prevalence of fecal indicator microorganisms in various water bodies of Birgunj sub-metropolitan city

\begin{tabular}{|c|c|c|c|c|c|c|c|}
\hline \multirow[t]{2}{*}{ Study time } & \multirow[t]{2}{*}{ Location } & \multicolumn{2}{|c|}{ Fecal Indieator Protozoon } & \multicolumn{4}{|c|}{ Fecal indicator Coliform bacteria } \\
\hline & & $\begin{array}{l}\text { Cryptospo- } \\
\text { ridium }\end{array}$ & Cinndia & Ev coli & Citrobacter & Ktebsiella & $\begin{array}{l}\text { Entero- } \\
\text { bacter }\end{array}$ \\
\hline \multirow[t]{6}{*}{ June 2015} & Site 1 & + & + & + & + & + & + \\
\hline & Site 2 & + & + & + & + & + & + \\
\hline & Site 3 & + & + & + & + & + & + \\
\hline & Site 4 & + & + & + & + & + & + \\
\hline & Site 5 & + & + & + & + & + & + \\
\hline & Site 6 & + & + & + & + & + & + \\
\hline \multirow{6}{*}{$\begin{array}{l}\text { Septem- } \\
\text { ber } 2015\end{array}$} & Site 1 & + & + & + & + & + & + \\
\hline & Site 2 & + & + & + & + & + & + \\
\hline & Site 3 & + & + & + & + & + & + \\
\hline & Site 4 & + & + & + & + & + & + \\
\hline & Site 5 & + & + & + & + & + & + \\
\hline & Site 6 & + & + & + & + & + & + \\
\hline \multirow{6}{*}{$\begin{array}{c}\text { December } \\
2015\end{array}$} & Site 1 & + & + & + & + & + & + \\
\hline & Site 2 & + & + & + & + & + & + \\
\hline & Site 3 & + & + & + & + & + & + \\
\hline & Site 4 & + & + & + & + & + & + \\
\hline & Site 5 & + & + & + & + & + & + \\
\hline & Site 6 & + & + & + & + & + & + \\
\hline \multirow{6}{*}{$\begin{array}{c}\text { March } \\
2016\end{array}$} & Site 1 & + & + & + & + & + & + \\
\hline & Site 2 & + & + & + & + & + & + \\
\hline & Site 3 & + & + & + & + & + & + \\
\hline & Site 4 & + & + & + & - & - & + \\
\hline & Site 5 & + & + & + & + & + & + \\
\hline & Site 6 & + & + & + & + & + & + \\
\hline \multirow[t]{6}{*}{ June 2016} & Site 1 & + & + & + & + & + & + \\
\hline & Site 2 & + & + & + & + & + & + \\
\hline & Site 3 & + & + & + & + & + & + \\
\hline & Site 4 & + & + & + & - & - & - \\
\hline & Site 5 & + & + & + & + & + & + \\
\hline & Site 6 & + & + & + & + & + & + \\
\hline
\end{tabular}

+, Positive; -, Negative; ND, Not detected. All indicator organism were grown in selective media that differs from one to other organism (see details in material \& methods). 
data shows that site 1 shows gradual increase of MPN up to December 2015, that might be the dilution of water during rainy season and after the rain the microorganism colonize rapidly. (Fig. 3)

After identification of present microoprganisms, it is reported here that speciesof Citrobacter, Enterobacter, Klebsiella, Escherichia coli, Cryptosporidium and Giardia were prevalent in almost all sites from June 2015 to December 2015 (Table 1). However, Citrobacter \& Klebsiella were not reported in site number 4 after $M$ arch 2016. Similarly, Klebsiella was also absent in site number 4 in June 2016. Whereas, Escherichia coli, Cryptosporidium and Giardia were regularly present in all sites (Table $1 \&$ Table 2). Site number 4 is situated in the ward number $B$ of Birgunj munisipility; so can say that ODF program is relatively more successful in ward number 13 . Fig $4 \mathrm{~A} \& \mathrm{~B}$ shows growth of $E$. coli on two different media agar plate (Mac Conkey agar plate $\&$ EM B repectively).

Similar studies in different part of Nepal is more or less same. Devkota (2011) conducted a study on "Open Defecation Free Situation" in Nepal. Hefound that only $92 \%$ households used toilets. Out of $92 \%, 14 \%$ households had partially functional toilets and $3 \%$ had nonfunctional toilets (Devkota, 2011). Thus, there is a big question of sustainability of ODF in the context of Nepal. Thereare some stories of failure of O DF in Nepal. In 2004, Government of Nepal targeted to provide $100 \%$ latrinein all houses providing sanitation facilities all over the country by 2017 (GoN, 2004). Although, this study did not attempted to collect the data of larine in houses, but the target of the

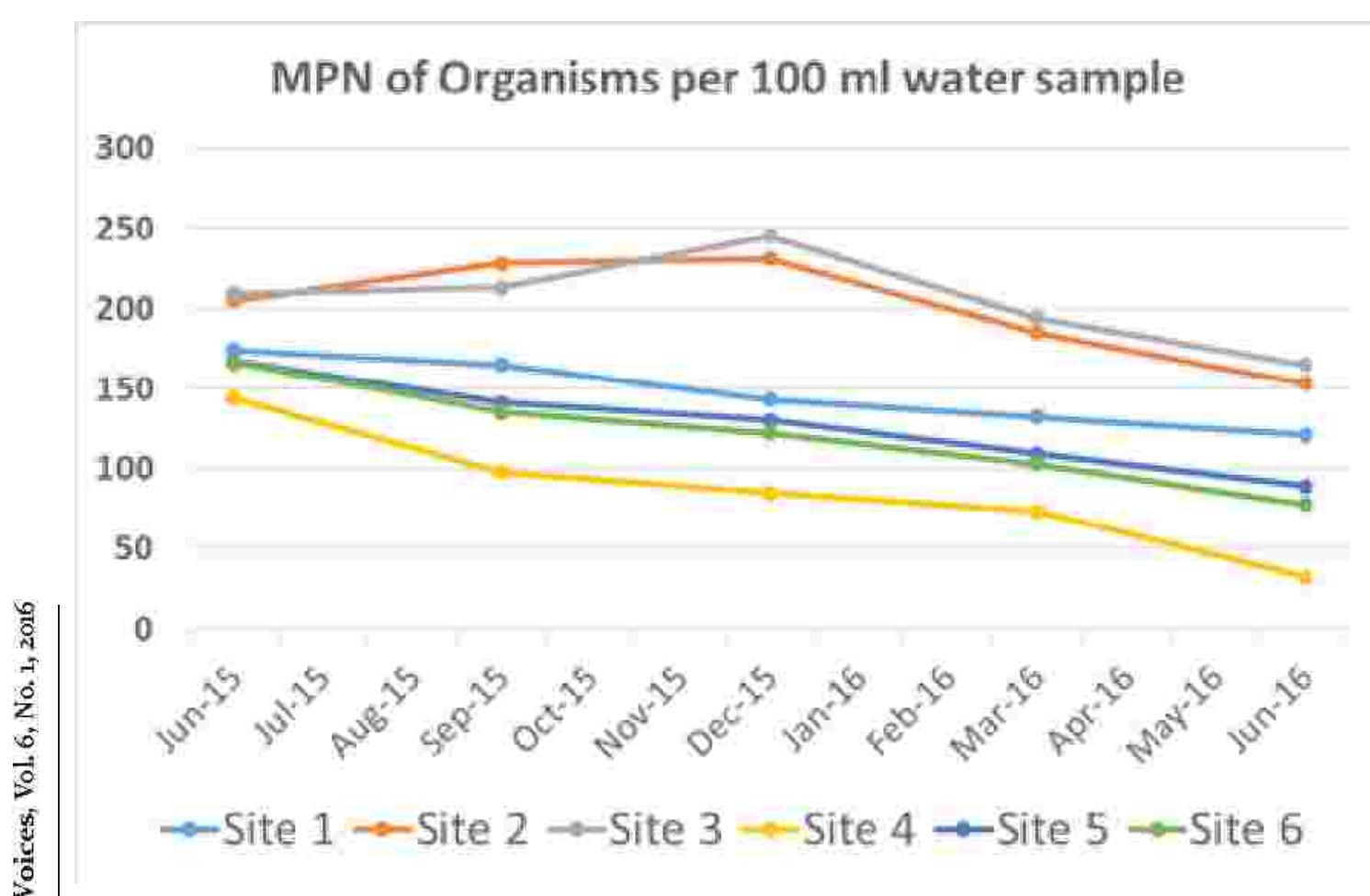

Fig. 3 : Graph showing the MPN of organisms per $100 \mathrm{ml}$ water samples analysed with time interval. Six sites were analysed. Site 1located in ward number 2; Site 2 \& site 3 located in ward number 18; Site 4 located in ward number 13; Site 5 located in ward number 15 and Site 6 located in ward number 17. 

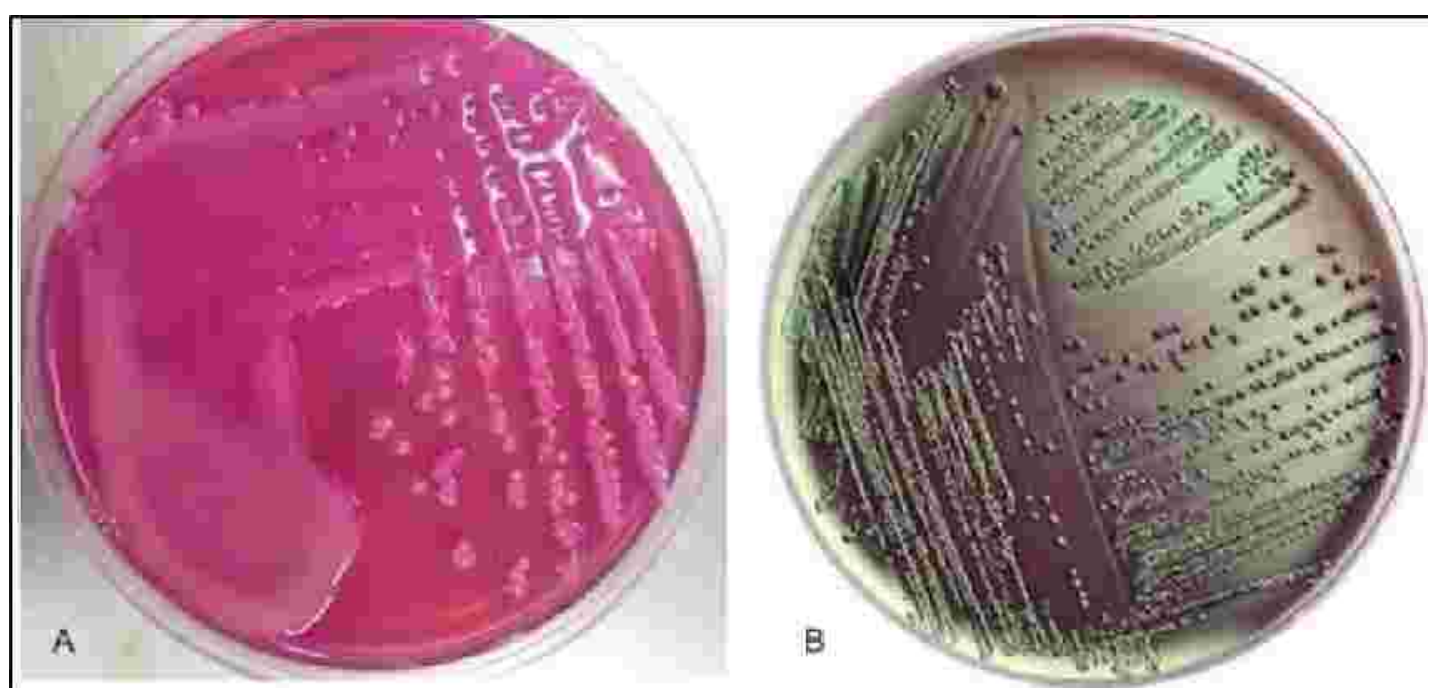

Fig 4 E. coli growth on two different media. A Mac Conkey agar plate B. EMB agar plate.

government of Nepal to provide $100 \%$ latrine in all houses seems incomplete till this report.

\section{Conclusion}

In conclusion, the ODF campaign and certification of ODF wards by Birgunj municipality is partially successful. However, some moreattempts for post ODF monitoring is essential for sustainable ODF.

Some sort of educating the people for health $\&$ hygienic practices should be arranged in some time interval is various wards. Many people feel easy outside urination and disposal of fecal material although they have latrine facility in their houses. Public toilet facility is the city is not enough to meet the requirements of people in moving for work at various places. NGOs should be involved for better result in health \& hygiene program including ODF campaign.

\section{References}

Adam, R. D. (2001). Biology of Giardia lamblia. Clin. Microbiol. Rev. 14(3), 447475. doi:10.1128/CM R. 14.3.447-475. 2001

American Public Health Association (APHA) (1995). Standard Methods for the
Examination of Water and Wastewater (19th ed.), APH A, Washington, DC

Atwill, E. R., Pereira, M. D. G. C., Alonso, L. H., Elmi, C., Epperson, W. B., Smith, R., ... \& Hoar, B. (2006). Environmental Load of Oocysts from Cattle Manure in Feedlots from the Central and Western United States. Journal of environmental quality, 35(1), 200-206.

Benson, H. J. (1998) Microbiological applications: A laboratory manual in general microbiology. McGraw-Hill College.

Devkota, B. (2011). An Operational Study on Open Defecation Free (ODF) Situation' in Nepal. Kath mandu: Water Aid.

GoN (2004). Rural Water Supply and Sanitation Policy and Rural Water Supply and Sanitation National Strategy. Kathmandu: Ministry of Physical Planning and Works, Government of Nepal.

Hogan, J. N., Daniels, M. E., Watson, F. G., Conrad, P. A., O ates, S. C., Miller, M. A., ... \&Jessup, D. A. (20D). Longitudinal Poisson regression to evaluate the epidemiology of Cryptosporidium, Giardia, and fecal 
indicator bacteria in coastal California wetlands. Applied and environmental microbiology, 78(10), 3606-3613.

Scallan, E., Griffin, P. M.; Angulo, F. J.; Tauxe, R. V., \& Hoekstra, R. M. (2011). Foodborne illness acquired in the United Statesunspecified agents. Emerg Infect Dis, $17(1)$, 16-22.

Sobsey, M. D. and Pfaender, F. K. (2002). Evaluation of $\mathrm{H} 2 \mathrm{~S}$ method for detection of faecal contamination of drinking water. Geneva, WHO/SDE/WSH/02.08.

Sponseller, J. K.; Griffiths JK, Tzipori, S. (2014). The evolution of respiratory Cryptosporidiosis: evidence for transmission by inhalation. Clin.
Microbiol. Rev. 27 (3), 575-586. doi:10.1128/ CMR.00115-13

Erlandsen, S. L., \& Meyer, E. A. (Eds.). (1984). Giardia and Giardiasis: Biology, Pathogenesis, and Epidemiology. Springer. pp. 131-. ISBN 978-0-306-41539-5.

The Microbiology of Drinking Water (2002) - Part 1 -(h2o) Water Quality and Public Health; Department of the Environment

Todar, K. (2007). Pathogenic E. coli. Online Textbook of Bacteriology, 34-67.

Van Donsel, D. J.; Geldreich, E. E., \& Clarke, N. A. (1967). Seasonal variations in survival of indicator bacteria in soil and their contribution to storm-water pollution. Applied Microbiology, 15(6), 1362-1370. 